\title{
Front Matter: Volume 6469
}

, "Front Matter: Volume 6469," Proc. SPIE 6469, Optical Components and Materials IV, 646901 (1 March 2007); doi: 10.1117/12.727083

SPIE Event: Integrated Optoelectronic Devices 2007, 2007, San Jose, California, SPIE. United States 


\section{PROCEEDINGS OF SPIE}

\section{Optical Components and Materials IV}

Shibin Jiang

Michel J. F. Digonnet

Editors

22-24 January 2007

San Jose, California, USA

Sponsored and Published by

SPIE-The International Society for Optical Engineering

Volume 6469

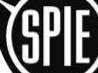


The papers included in this volume were part of the technical conference cited on the cover and title page. Papers were selected and subject to review by the editors and conference program committee. Some conference presentations may not be available for publication. The papers published in these proceedings reflect the work and thoughts of the authors and are published herein as submitted. The publisher is not responsible for the validity of the information or for any outcomes resulting from reliance thereon.

Please use the following format to cite material from this book:

Author(s), "Title of Paper," in Optical Components and Materials IV, edited by Shibin Jiang, Michel J. F. Digonnet, Proceedings of SPIE Vol. 6469 (SPIE, Bellingham, WA, 2007) Article CID Number.

ISSN 0277-786X

ISBN 9780819465825

Published by

SPIE-The International Society for Optical Engineering

P.O. Box 10, Bellingham, Washington 98227-0010 USA

Telephone 1 360/676-3290 (Pacific Time) · Fax 1 360/647-1445

http://www.spie.org

Copyright @ 2007, The Society of Photo-Optical Instrumentation Engineers

Copying of material in this book for internal or personal use, or for the internal or personal use of specific clients, beyond the fair use provisions granted by the U.S. Copyright Law is authorized by SPIE subject to payment of copying fees. The Transactional Reporting Service base fee for this volume is $\$ 18.00$ per article (or portion thereof), which should be paid directly to the Copyright Clearance Center (CCC), 222 Rosewood Drive, Danvers, MA 01923. Payment may also be made electronically through CCC Online at http://www.copyright.com. Other copying for republication, resale, advertising or promotion, or any form of systematic or multiple reproduction of any material in this book is prohibited except with permission in writing from the publisher. The CCC fee code is 0277 $786 \times / 07 / \$ 18.00$.

Printed in the United States of America. 


\section{Contents}

ix Conference Committee

\section{SESSION 1 THIN-FILM COMPONENTS}

646903 Design of wideband optical polarizing films for visible region using oblique metal island films [6469-02]

K. Baba, Y. Kakinuma, Sendai National College of Technology (Japan)

646904 Optical switching with a thermochromic film [6469-03]

L. Men, Q. Chen, Memorial Univ. of Newfoundland (Canada)

646905 Time dependence of internal stress and optical characteristics of $\mathrm{SiO}_{2}$ optical thin film [6469-04]

H. Murotani, K. Arai, M. Wakaki, Tokai Univ. (Japan)

646906 Active resonant subwavelength grating for scannerless range imaging sensors [6469-05]

S. A. Kemme, R. R. Boye, D. W. Peters, R. O. Nellums, Sandia National Labs. (USA)

\section{SESSION 2 CERAMICS AND NANOCRYSTALS}

646908 Novel photonics materials for broadband lightwave processing (Invited Paper) [6469-07]

Y. Ohishi, Toyota Technological Institute (Japan)

646909 Ceramization of erbium activated planar waveguides by bottom up technique [6469-08]

Y. Jestin, CNR-IFN (Italy); C. Arfuso-Duverger, Lab. des Oxydes et Fluorures, CNRS, Univ. du Maine (France); C. Armellini, CNR-IFN (Italy); B. Boulard, Lab. des Oxydes et Fluorures, CNRS, Univ. du Maine (France); A. Chiappini, Univ. di Trento (Italy); A. Chiasera, M. Ferrari, CNR-IFN (Italy); E. Moser, Univ. di Trento (Italy); G. Nunzi Conti, S. Pelli, Nello Carrara Institute of Applied Physics, IFAC-CNR (Italy); O. Peron, Lab. Oxydes et Fluorures, CNRS, Univ. du Maine (France); R. Retoux, Lab. CRISMAT, ENSICAEN (France); G. C. Righini, CNR (Italy)

Pagination: Proceedings of SPIE follow an e-First publication model, with papers published first online and then in print and on CD-ROM. Papers are published as they are submitted and meet publication criteria. A unique, consistent, permanent citation identifier (CID) number is assigned to each article at the time of the first publication. Utilization of CIDs allows articles to be fully citable as soon they are published online, and connects the same identifier to all online, print, and electronic versions of the publication.

SPIE uses a six-digit CID article numbering system in which:

- The first four digits correspond to the SPIE volume number.

- The last two digits indicate publication order within the volume using a Base 36 numbering system employing both numerals and letters. These two-number sets start with 00, 01, 02, 03, 04, 05, 06, 07, 08, 09, OA, OB ... 0Z, followed by 10-1Z, 20-2Z, etc.

The CID number appears on each page of the manuscript. The complete citation is used on the first page, and an abbreviated version on subsequent pages. 
64690A Spectroscopic studies and AFM analysis of $\mathrm{Ho}^{3+}$ and $\mathrm{Tm}^{3+}$ doped yttrium oxide nanoparticles [6469-09]

D. Patel, C. Perry, S. Kennedy, Oakwood College (USA)

64690B A hybrid sol-gel reverse-mesa waveguide using lanthanide phosphate nanoparticles for optical amplification [6469-10]

H. Gan, L. Li, C. T. DeRose, R. A. Norwood, College of Optical Sciences, Univ. of Arizona (USA); C. R. De Silva, Z. Zheng, Univ. of Arizona (USA); N. Peyghambarian, College of Optical Sciences, Univ. of Arizona (USA)

64690C 2.6-watt average-power mode-locked ceramic Nd:YAG laser [6469-11]

J. A. Wisdom, D. S. Hum, M. J. F. Digonnet, Stanford Univ. (USA); A. Ikesue, World-Labo Co., Ltd. (Japan); M. M. Fejer, R. L. Byer, Stanford Univ. (USA)

\section{SESSION 3 EXOTIC GLASSES}

64690D Concentration dependence of the fluorescence decay profile in transition metal doped chalcogenide glass [6469-12]

M. Hughes, D. W. Hewak, Univ. of Southampton (United Kingdom); R. J. Curry, Univ. of Surrey (United Kingdom)

64690E Mid-infrared fiber laser application: $\mathrm{Er}^{3+}$ doped chalcogenide glasses [6469-13] V. Moizan, CNRS, Sciences chimiques de Rennes, Univ. de Rennes I (France) and ONERADOTA (France); V. Nazabal, J. Troles, P. Houizot, J.-L. Adam, CNRS, Sciences chimiques de Rennes, Univ. de Rennes I (France); F. Smektala, CNRS, Institut Carnot de Bourgogne, Univ. de Bourgogne (France); J.-L. Doualan, R. Moncorgé, CIRIL-ENSICAEN (France); G. Canat, J.-P. Cariou, ONERA-DOTA (France)

64690F Recent advances in laser-induced cooling in rare-earth doped low phonon materials (Invited Paper) [6469-14]

A. J. García-Adeva, Escuela Superior de Ingenieros (Spain); R. Balda, J. Fernández, Escuela Superior de Ingenieros (Spain), Unidad Fisica de Materiales CSIC-UPV/EHU and DIPC (Spain)

$64690 \mathrm{~S}$ Systematic and material independent variation of electrical, optical, and chemical properties of Ln-materials over the Ln-series (Ln=La,Ce,Pr,...Lu) [6469-15]

E. van der Kolk, P. Dorenbos, Delft Univ. of Technology (Netherlands)

\section{SESSION 4 LASERS AND AMPLIFIERS}

$64690 \mathrm{H} \quad$ Fiber designs for high power lasers (Invited Paper) [6469-16]

M.-J. Li, X. Chen, J. Wang, A. Liu, S. Gray, D. T. Walton, A. B. Ruffin, J. Demeritt, L. Zenteno, Corning Inc. (USA)

64690J Advanced waveguide lasers fabricated by femtosecond laser writing in an Er:Yb-doped phosphate glass [6469-18]

G. Della Valle, R. Osellame, S. Taccheo, N. Chiodo, G. Galzerano, G. Cerullo, P. Laporta, R. Ramponi, Istituto di Fotonica e Nanotecnologie, CNR, Politecnico di Milano (Italy); U. Morgner, Univ. of Hannover (Germany); A. G. Rozhin, V. Scardaci, A. C. Ferrari, Cambridge Univ. (United Kingdom) 
64690K Ultra-broadband Raman gain media for photonics device applications [6469-19]

R. Jose, Y. Ohishi, Toyota Technological Institute (Japan)

64690L Measurement of the stimulated Brillouin scattering gain coefficient of a phosphate fiber [6469-20]

Y. W. Lee, K. E. Urbanek, M. J. F. Digonnet, R. L. Byer, Stanford Univ. (USA); S. Jiang, NP

Photonics (USA)

\section{SESSION 5}

BULK COMPONENTS

64690M Large aperture tunable ultra narrow band Fabry-Perot-Bragg filter [6469-21]

J. Lumeau, CREOL, Univ. of Central Florida (USA); V. Smirnov, OptiGrate (USA);

F. Lemarchand, M. Lequime, Institut Fresnel, CNRS, Univ. Paul Cézanne (France);

L. B. Glebov, CREOL, Univ. of Central Florida (USA)

64690N Diffractive lens for matter-wave beams [6469-22]

R. R. Letfullin, Rose-Hulman Institute of Technology (USA); T. F. George, Univ. of Missouri, St. Louis (USA)

646900 A single crystal photo-elastic-modulator [6469-23]

F. Bammer, B. Holzinger, T. Schumi, Vienna Univ. of Technology (Austria)

64690P Semiconductor saturable absorbers with recovery time controlled by lattice mismatch [6469-24]

M. D. Guina, Tampere Univ. of Technology (Finland) and RefleKron Ltd. (Finland);

S. Suomalainen, T. Hakulinen, O. G. Okhotnikov, Tampere Univ. of Technology (Finland);

S. Marcinkevicius, Royal Institute of Technology (Sweden)

64690Q Low-loss low-voltage AIGaAs/GaAs high-speed optical switch with doping and composition graded heterojunction interfaces [6469-25]

L. Sun, J. Noad, R. James, D. Coulas, S. Cao, G. Lovell, E. Higgins, Communications

Research Ctr. (Canada)

\section{SESSION 6 FIBER COMPONENTS}

64690R Fiber AOTF with record large FSR and its application as an NIR spectrometer [6469-26]

Q. Li, S. X. Wang, B\&W Tek, Inc. (USA)

64690S A novel optical tuning technology [6469-27]

N. Miron, ROCTEST (Canada)

64690 Development of soft-glasses photonic crystal fiber made by stacking-and-draw technique [6469-29]

E. F. Chillcce, C. M. B. Cordeiro, R. S. Ramos, B. C. Z. Honório, E. Rodriguez, G. J. Jacob,

C. H. Brito Cruz, C. L. Cesar, L. C. Barbosa, Univ. Estadual de Campinas (Brazil)

64690 Star cross section polymer fiber for evanescent field optical sensors [6469-30]

E. F. Chillcce, W. M. Faustino, G. J. Jacob, E. Rodriguez, W. M. Moreira, C. L. Cesar,

L. C. Barbosa, Univ. Estadual de Campinas (Brazil) 
64690W Photosensitivity of optical fiber gratings and sensing applications [6469-31]

Q. Chen, P. LU, L. Men, Memorial Univ. of Newfoundland (Canada)

64690X Electric-arc-induced long period fiber gratings for gain equalization of erbium-doped optical amplifiers [6469-32]

I. Cacciari, M. Brenci, R. Falciai, CNR-Nello Carrara Institute of Applied Physics (Italy); G. Nunzi Conti, Centro Fermi (Italy) and CNR-Nello Carrara Institute of Applied Physics (Italy); S. Pelli, CNR-Nello Carrara Institute of Applied Physics (Italy); G. C. Righini, CNR-Nello Carrara Institute of Applied Physics (Italy) and CNR (Italy)

64690Y A study of silver-film ion-exchanged glass waveguides in phosphate glass [6469-49]

S. Yliniemi, Helsinki Univ. of Technology (Finland); J. Albert, Carleton Univ. (Canada);

S. Honkanen, College of Optical Sciences, Univ. of Arizona (USA)

\section{POSTER SESSION}

$64690 Z$ Quarter wave retarders for dense wave division multiplexing [6469-33]

M. A. Habli, Sultan Qaboos Univ. (Oman)

646910 Characterization of light scattering and film structure of $\mathrm{TiO}_{2}$ thin film [6469-34]

H. Murotani, T. Kudo, M. Wakaki, Tokai Univ. (Japan)

646911 Simple chromatic dispersion measurement method using a spectral interferometer [6469-36]

J. Y. Lee, I. H. Shin, S. R. Lee, T. Wei, D. Y. Kim, Gwangju Institute of Science and Technology (South Korea)

646913 Codoped materials for high power fiber lasers: diffusion behaviour and optical properties [6469-38]

S. Unger, A. Schwuchow, J. Dellith, J. Kirchhof, Institut für Physikalische Hochtechnologie

e.V. (Germany)

646914 Stable system technique for measuring the refractive index profile of an optical fiber by modified fiber-type confocal microscope method [6469-39]

S. B. Cho, Y. Youk, D. Y. Kim, Gwangju Institute of Science and Technology (South Korea)

646915 Use of $\mathrm{CsCl}$ to enhance the glass stability range of tellurite glasses for $\mathrm{Er}^{3+}$ doped optical fiber drawing [6469-40]

C. R. Eyzaguirre, E. Rodriguez, E. F. Chillcce, S. P. Amaral Osório, C. Lenz Cesar, I. Odone Mazali, O. Luiz Alves, L. Carlos Barbosa, Univ. Estadual de Campinas (Brazil)

646916 Equilibrium-state emission of electron-trapping material thin-film for applications in nonlinear-dynamics [6469-41]

R. Pashaie, N. Farhat, Univ. of Pennsylvania (USA)

646917 A reconsideration of birefringent interleaver [6469-44]

C.-H. Cheng, Miami Univ. (USA)

646918 Novel rare earth doped tellurite glasses for fiber lasers in the 2-micron wavelength region [6469-45]

D. Milanese, M. Vota, G. Liao, M. Ferraris, Politecnico di Torino (Italy); N. Coluccelli,

S. Taccheo, Politecnico di Milano (Italy) 
64691A A miniature electro-optic switch array [6469-48]

X. LU, Univ. of Massachusetts Lowell (USA); M. Li, PICC Property and Casualty Co., Ltd. (China)

Author Index 
Downloaded From: https://www.spiedigitallibrary.org/conference-proceedings-of-spie on 25 Apr 2023

Terms of Use: https://www.spiedigitallibrary.org/terms-of-use 


\title{
Conference Committee
}

\author{
Symposium Chair \\ Yakov Sidorin, Photineer Technology Group (USA) \\ Symposium Cochair
}

Ali Adibi, Georgia Institute of Technology (USA)

Program Track Chair

James G. Grote, Air Force Research Laboratory (USA)

Conference Chairs

Shibin Jiang, NP Photonics, Inc. (USA)

Michel J. F. Digonnet, Stanford University (USA)

\section{Program Committee}

Jean-Luc Adam, Université de Rennes I (France)

John M. Ballato, Clemson University (USA)

Robert Dahlgren, Silicon Valley Photonics, Ltd. (USA)

J. Gary Eden, University of Illinois at Urbana-Champaign (USA)

Simon C. Fleming, The University of Sydney (Australia)

François Gonthier, ITF Optical Technologies, Inc. (Canada)

Jong Heo, Pohang University of Science and Technology (South Korea)

Animesh Jha, University of Leeds (United Kingdom)

Steven T. Johns, Air Force Research Laboratory (USA)

Jacques Lucas, Université de Rennes I (France)

Barrett G. Potter, Jr., The University of Arizona (USA)

David Pureur, HighWave Optical Technologies (France)

Kathleen A. Richardson, Clemson University (USA)

Giancarlo C. Righini, Istituto di Fisica Applicata Nello Carrara, CNR (Italy)

Stan M. Smith, U.S. Army Space and Missile Defense Command (USA)

Feng Song, Nankai University (China)

Setsuhisa Tanabe, Kyoto University (Japan)

Ji Wang, Corning Inc. (USA)

John M. Zavada, U.S. Army Research Office (USA)

Session Chairs

1 Thin-Film Components

Shibin Jiang, NP Photonics, Inc. (USA) 
2 Ceramics and Nanocrystals

Michel J. F. Digonnet, Stanford University (USA)

3 Exotic Glasses

Shibin Jiang, NP Photonics, Inc. (USA)

$4 \quad$ Lasers and Amplifiers

Michel J. F. Digonnet, Stanford University (USA)

5 Bulk Components

Shibin Jiang, NP Photonics, Inc. (USA)

6 Fiber Components

Michel J. F. Digonnet, Stanford University (USA) 